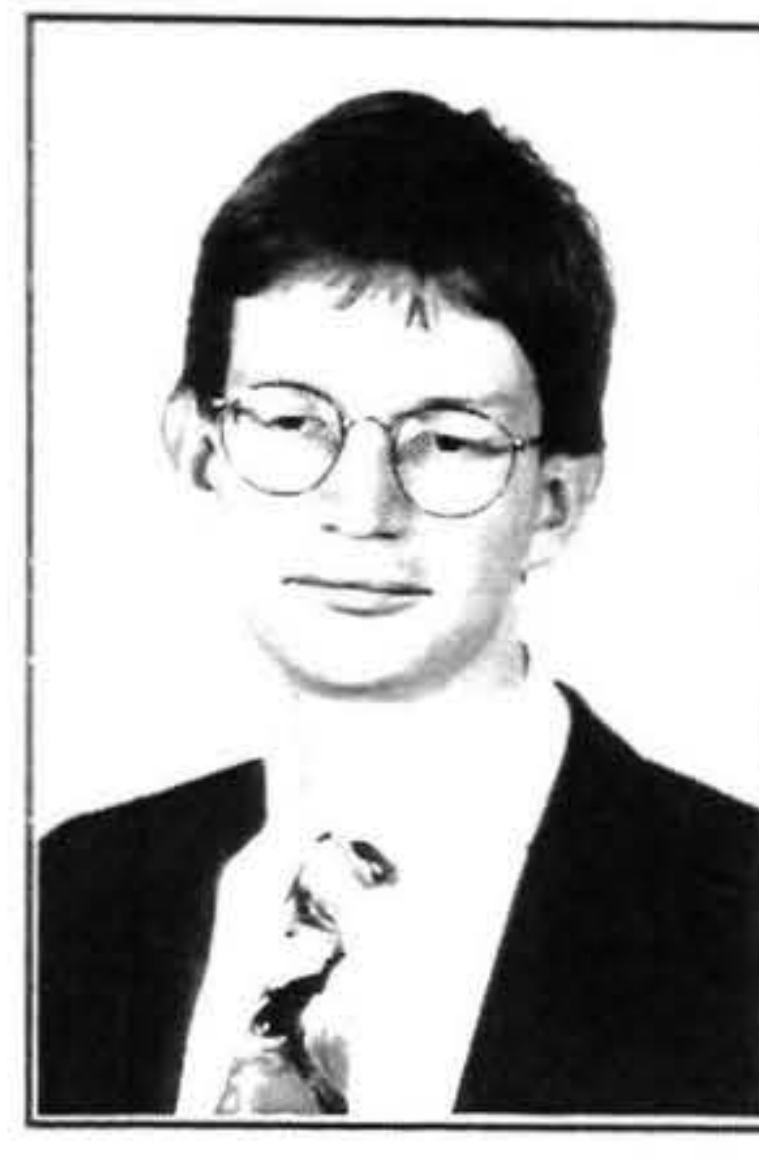

\title{
THE TRANSITION TO EMPLOYMENT: AN ANALYSIS OF GROSS FLOWS FROM THE HOUSE- HOLD LABOUR FORCE SURVEY
}

\author{
Stuart Irvine \\ Statistics New Zealand
}

\begin{abstract}
Following a steady increase over about five years, the number of people unemployed finally began to fall towards the end of 1991. Changes in unemployment numbers were reflected, to a degree, in employment numbers. Employment fell during most of the late 1980s, and a sustained rise in employment numbers did not occur until early in 1992. Falls in unemployment occur as the number of people moving into unemployment is exceeded by the number of people moving out of unemployment. Similarly, increases in employment result from a net inflow into employment. Of all the people who are not employed in one period, some have a higher probability than others of being employed in the next period. Using gross-flows data from all the 35 quarters of the Household Labour Force Survey, this paper examines the effect of selected characteristics on the probability of moving into employment, and how the effect of these characteristics has changed over time. Four characteristics are examined: occupation sought, job search method, length of time since last employment and educational attainment.
\end{abstract}

Over the past eight years unemployment has emerged as one of the most worrying social and economic problems facing New Zealanders. While unemployment was of only minor concern in the mid-1980s, throughout the late 1980 s and the early 1990 s unemployment grew rapidly. In 1992, official unemployment peaked at over 180,000 persons or 11.1 percent of the labour force.

Furthermore, in the March 1992 quarter, 80,000 persons (or 48 percent of the unemployed) were long-term unemployed (ie had been unemployed for more than 26 weeks). It is widely accepted that people who are unemployed long-term have more difficulty finding work than those who have been unemployed for a shorter period of time.

While unemployment numbers have now begun to decline significantly, the latest figures (those for the June 1994 quarter) show that unemployment at 137,500 is still twice the level of seven years ago. Moreover, at 50 percent, ${ }^{2}$ the percentage of the unemployed who are long-term unemployed is historically very high.

The experience of unemployment is different for different people. Some remain unemployed for only a short time, while others will be without work for a number of years. Clearly the unemployed are not a homogenous group. Policy initiatives designed to assist the unemployed into work usually recognise this, and target certain groups.

Using gross-flows data from the Household Labour Force Survey (HLFS), Grimmond (1993a), shows that the probability of exiting unemployment varies with age, sex, qualifications, ethnicity, occupation, industry, geographic location and duration of unemployment. ${ }^{3}$

Using a similar methodology, this paper explores the effect of five variables on the probability of exiting unemployment. These variables are educational attainment, part-time / fulltime status, occupation sought, work experience and job search method. The movements of those people who are not in the labour force (neither employed or unemployed) into the labour force are also considered. The Job Plus programme provides a good example. Under this programme, wage subsidies are paid to employers (for a fixed duration) to assist long-term (or otherwise disadvantaged) job seekers into permanent fulltime employment. The target group of this programme are those who have been registered as unemployed for 26 weeks or more as well as those who are assessed as being particularly disadvantaged in the labour market.

The gross-flows data presented in this paper are average figures relating to the period March 1986 to June 1994. To allow a comparison over time, this period has been divided into two. The first period is March 1986 to March 1990 (comprising 17 quarters), while the second period is September 1990 to June 1994 (comprising 16 quarters). ${ }^{4}$ The paper begins with a brief look at the extent of unemployment as shown by statistics on the duration of unemployment. The concept of gross-flows data is explained and the results of their analysis is presented. Opportunities for further research are then discussed.

\section{Unemployment duration}

Table 1 shows that of the 155,400 people unemployed in 
the year to March 1994, 75,300 (or 52.5 percent of those specifying a duration) were long-term unemployed. Furthermore, 47,000 (32.8 percent) had been unemployed for more than one year, 22,100 (15.4 percent) for more than two years and 11,900 ( 8.3 percent) for over three years.

These figures do not compare favourably with five years earlier when there were 28,400 long-term unemployed (or 40.3 percent of those specifying a duration). Of these, 11,900 (or 14.2 percent) had been unemployed for more than one year. These statistics on duration of unemployment suggest that between 1989 and 1994 the number of people remaining unemployed for long periods of time increased and people became more likely to remain unemployed from one period to the next.

\section{Background to gross flows methodology}

On the basis of their responses, all respondents to the Household Labour Force Survey are allocated a labour force status of either employed, unemployed or not in the labour force. The employed and the unemployed comprise the labour force, while the labour force and the not in the labour force group together, comprise the working-age population. Each dwelling (usually a house) remains in the survey for two years. The survey is administered quarterly (every three months) and so each dwelling is surveyed eight times.

Gross-flows data are generated by comparing the labour force status of each respondent in one quarter, with their labour force status in the subsequent quarter. Those individuals who participate in the survey in consecutive quarters are termed the matched sample. Those individuals who are in the survey for only one of two quarters being considered are termed the unmatched sample.

The sample of the Household Labour Force Survey comprises eight rotation groups. One rotation group is rotated out of the survey each quarter, while a new rotation group in rotated in each quarter. Theoretically then, the maximum percentage of respondents that can be matched between quarters is 87.5 percent. In practice however, only about 75 percent of respondents are matched for one of more of the following reasons:

* persons turn 15 between the previous and current quarters (enter the working-age population).

* persons present in the previous quarter die before the current quarter.

* persons are not able to be contacted in one of the quarters.

* persons shift from, or move into, the dwelling between quarters.

${ }^{*}$ persons refuse in one quarter and respond in the other.

The unmatched sample therefore comprises about 25 percent of the total, with about half its members resulting from the rotation pattern and half from other causes.

The characteristics of the matched and the unmatched sample are usually slightly different, for example, the matched sample consistently under-represents the unem-

Table 1a. Persons unemployed by duration of unemployment ('000) 1987-1990

\begin{tabular}{llllllll}
\hline $\begin{array}{l}\text { Average for } \\
\text { year ended } \\
\text { March }\end{array}$ & $\begin{array}{l}\text { Short-term } \\
\text { 26 weeks } \\
\text { or less }\end{array}$ & $\begin{array}{l}\text { Long-term } \\
27-52 \\
\text { weeks }\end{array}$ & $\begin{array}{l}1-2 \\
\text { years }\end{array}$ & 2-3 years & $\begin{array}{l}\text { Over 3 } \\
\text { years }\end{array}$ & $\begin{array}{l}\text { Not } \\
\text { Specified }\end{array}$ & Total \\
\hline 1987 & 37.0 & 7.6 & 4.6 & - & - & 14.8 & 64.0 \\
1988 & 39.5 & 9.6 & 5.9 & - & - & 14.5 & 69.5 \\
1989 & 55.5 & 16.5 & 11.9 & - & - & 14.1 & 98.0 \\
1990 & 61.0 & 18.7 & 18.0 & - & - & 14.7 & 112.4 \\
\hline
\end{tabular}

Source: Household Labour Force Survey

Table 1b. Persons unemployed by duration of unemployment ('000) 1991-1994

\begin{tabular}{llllllll}
\hline $\begin{array}{l}\text { Average for } \\
\text { year ended } \\
\text { March }\end{array}$ & $\begin{array}{l}\text { Short-term } \\
\text { 26 weeks } \\
\text { or less }\end{array}$ & $\begin{array}{l}\text { Long-term } \\
27-52 \\
\text { weeks }\end{array}$ & $\begin{array}{l}1-2 \\
\text { years }\end{array}$ & 2-3 years & $\begin{array}{l}\text { Over 3 } \\
\text { years }\end{array}$ & $\begin{array}{l}\text { Not } \\
\text { Specified }\end{array}$ & Total \\
\hline 1991 & 73.5 & 22.2 & 16.1 & 6.1 & 4.1 & 13.7 & 135.7 \\
1992 & 84.3 & 34.8 & 24.6 & 8.4 & 8.0 & 12.5 & 172.6 \\
1993 & 69.8 & 31.3 & 29.8 & 11.6 & 10.1 & 13.0 & 165.6 \\
1994 & 68.2 & 28.3 & 24.9 & 10.2 & 11.9 & 11.9 & 155.4 \\
\hline
\end{tabular}

Source: Household Labour Force Survey 
ployed and over-represents those not in the labour force.

These differences can be explained partially by differences in the age distribution of the matched and unmatched samples. For instance, the younger respondents (among whom unemployment is relatively high) have lower response rates than the older respondents (many of whom are not in the labour force).

People who shift house between one quarter and the next are not included in the matched sample. To the extent that such shifts are related to labour market dynamics, the exclusion of the unmatched sample in the calculation of gross-flows adds bias to the estimates. The differences between the matched and unmatched samples are discussed in detail by Woolf (1989) and by Grimmond (1993a).

\section{New sample}

The HLFS sample was recently redesigned. Commencing with the December 1993 quarter, one-quarter of the old sample of households was replaced with one-quarter of the new sample. This process continued for the following three quarters, so that in the September 1994 quarter, the sample consisted solely of households selected from the new sample.

During the transition phase, the maximum possible size of the matched sample is only 75 percent of the complete sample due to one-quarter of the sample being rotated out each quarter. However, the actual match is likely to be about 62.5 percent. For this reason, the quarters December 1993 through to June 1994 have been excluded from the calculations of average gross flows, although data relating to these quarters have been included in the calculation of transition probabilities. ${ }^{5}$

\section{Calculation of gross flows}

Table 2 shows the nine possible scenarios of labour force status in one quarter compared to the next. For example, if an individual was employed in the first quarter, then in the second quarter their employment status would be either employed, unemployed or not in the labour force. This is represented as EE, EU or EN respectively.

\section{Table 2: Gross-flows matrix}

Labour Force Status in second quarter

$\begin{array}{lllll} & & \mathbf{E} & \mathbf{U} & \mathbf{N} \\ \text { Labour force } & \mathbf{E} & \mathrm{EE} & \mathrm{EU} & \mathrm{EN} \\ \text { status in } & \mathbf{U} & \mathrm{UE} & \mathrm{UU} & \mathrm{UN} \\ \text { first quarter } & \mathbf{N} & \mathrm{NE} & \mathrm{NU} & \mathrm{NN}\end{array}$

From the gross-flows tables the transition probabilities can be calculated. For example, the probability of an individual being employed in the second quarter, given an employment status of 'unemployed' in the first quarter, is the gross flow UE divided by the total gross flow from employment in the second quarter. Grimmond (1993) provides the following notation:

$$
\mathrm{UETP}=\mathrm{UE} /(\mathrm{UE}+\mathrm{UU}+\mathrm{UN})
$$

where $\mathrm{TP}=$ transition probability

Figure 1 shows the various gross flows diagramatically. While the type of gross-flows data discussed above measures the flows between the various labour force statuses, the data do not provide a complete explanation for shifts in unemployment or employment because movements to and from the matched sample are not measured. These flows include the movement of people into the survey for the first time, respondents moving out of the survey (after being in the survey for two years), and the movement into and out of the survey as a result of non-response in the previous or current quarter. For example, a person who could not be conlacted in the June quarter, but was found to be employed in the September quarter could not be represented in a gross-flows calculation as no labour force status would be available for the first quarter. (If this same person were unemployed in the December quarter, then the gross-flows for September to December would be EU).

\section{Limitations of gross-flows data}

The main limitations of gross-flows data are listed below. More thorough discussion of these limitations is provided by both Woolf (1989) and Grimmond (1993a). The main limitations are:

* Multiple changes in labour force status (within a quarter) are not reflected in HLFS gross-flows data.

* Incorrect classification (eg in the case of proxy interviews) may register incorrectly as a flow from one labour force status to another. Estimates are also subject to other forms of non-sampling error such as errors in the coding and recording of data.

* Each individual in the survey is assigned a unique weight which varies from quarter to quarter because of sampling variability and changes in response rates. In calculating HLFS flows data for two consecutive quarters, the second period's weight is applied to the individual records. However, because it is the flow between quarters that is being measured, some mid-point weighting would be more representative. Such an alternative weighting system has yet to be developed.

* The HLFS is a sample survey and all estimates derived from it are subject to sampling error. The sampling errors associated with quarterly gross-flows estimates are generally higher than those associated with estimates which are not flow data. This is because the size of the matched sample is always smaller than the size of the complete sample, and because there are nine flows to estimate for gross-flows data compared with only three elements for labour force status. This paper is focuses mainly on averages cumulated over two four year periods. This cumulation reduces sampling error are and 


\section{Figure 1. Gross-flows relationships}

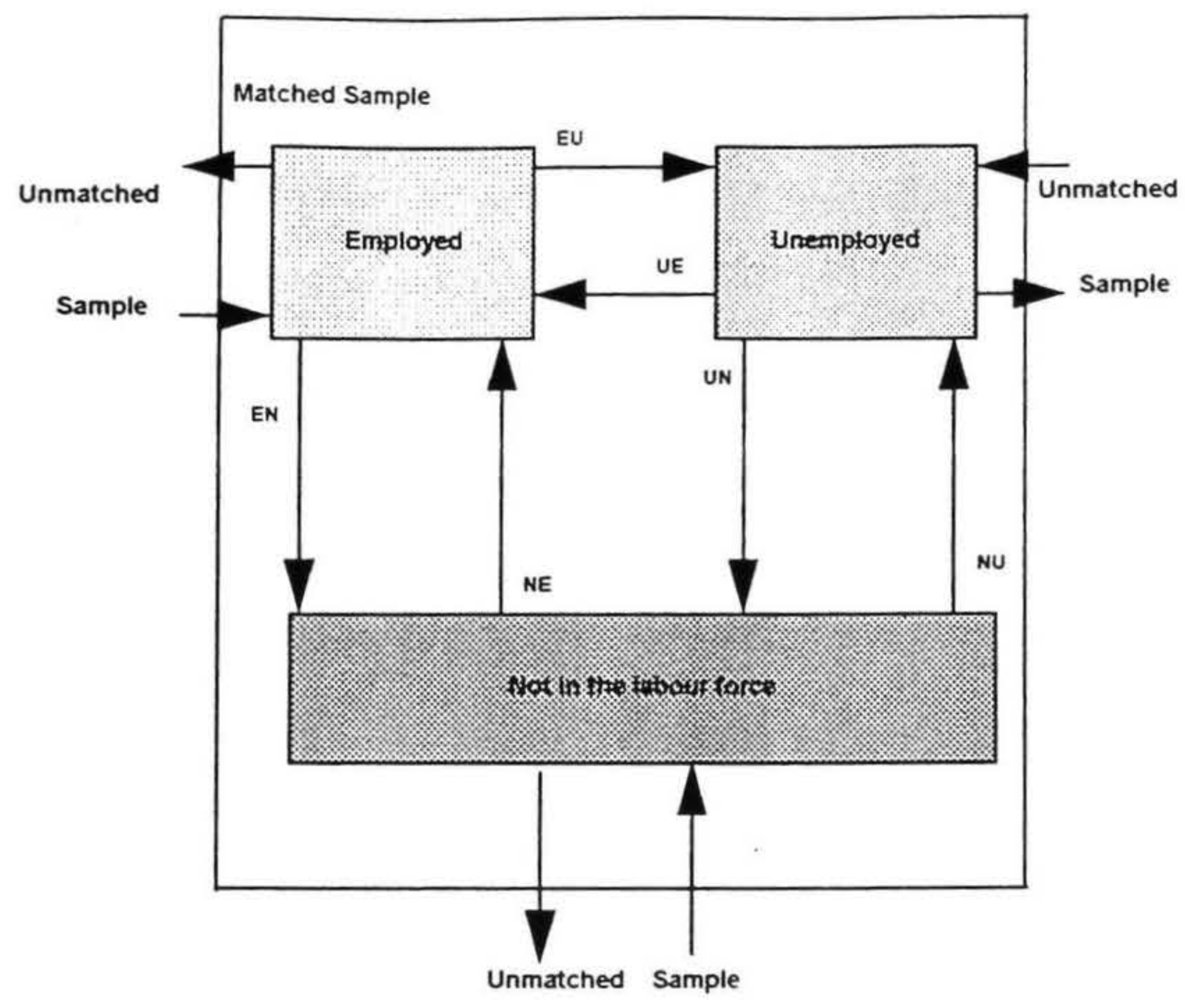

allows for analysis of more detailed sub-groups.

* The survey weights of the HLFS are designed so that the weighted sample totals estimate the target population totals. The estimates of gross-flows are calculated by summing the weights of respondents who were in the relevant category (eg UE) and were in the matched sample. The estimates of gross-flows do not relate to the entire target population because the unmatched sample is excluded. This means the gross flow totals, on their own, are not as meaningful as estimates which related to the total population. For this reason, this paper focuses mainly on the transition probabilities and on the size of the various gross-flows relative to each other.

\section{Results of analysis}

In the sections which follow, the various flows and transition probabilities from unemployment are examined in aggregate as well as by the categories of part-time / fulltime status, work experience, occupation sought, educational attainment and job search method. The flows from not in the labour force are also examined in aggregate and by part-time /fulltime status and educational attainment.

\section{Aggregate gross flows and transition probabilities}

The various gross flows and transition probabilities for the periods March 1986 to March 1990 and September 1990 to September 1993 (or June 1994) are shown in Table 3. The transition probabilities indicate that in the later period, the probability of an unemployed person obtaining employment was lower than for the earlier period. During the earlier period the unemployed had a 36 percent chance of being employed in the subsequent quarter, while in the later period the probability fell to 26 percent. Similarly, the probability of the unemployed withdrawing from the labour force fell from 28 percent in the earlier period to 25 percent in the later period.

Consequently, the unemployed were more likely to remain unemployed from one quarter to the next in the later period than in the earlier period ( 49 percent chance compared to a 37 percent chance).

These figures suggest that while the unemployed were less likely to obtain employment in the latter period, they were also slightly more likely to continue their job search (rather than withdrawing from the labour force). It is possible that while people were finding work just as often in the latter period, the work was only temporary and so within any one quarter a person may be moving into employment but moving out of employment shortly afterwards. Such people would register as either UU or UE (or EU) depending on the time they are surveyed. However, this possibility cannot be verified by gross-flows data because respondents of the Household Labour Force Survey are 
Table 3. Gross flows and transition probabilities, 1986 to 1994

\begin{tabular}{|c|c|c|c|c|c|c|}
\hline Period & NN & NE & NU & UN & UE & UU \\
\hline & \multicolumn{6}{|c|}{ Gross flows (000s) } \\
\hline 1986 to 1990 & 574.2 & 53.0 & 17.0 & 15.0 & 19.4 & 20.0 \\
\hline \multirow[t]{2}{*}{1990 to 1993} & 638.0 & 47.9 & 30.3 & 26.9 & 27.4 & 53.6 \\
\hline & \multicolumn{6}{|c|}{ Transition probabilities } \\
\hline 1986 to 1990 & 0.89 & 0.08 & 0.03 & 0.28 & 0.36 & 0.37 \\
\hline 1990 to 1994 & 0.89 & 0.07 & 0.04 & 0.25 & 0.26 & 0.49 \\
\hline
\end{tabular}

Source: Household Labour ForceSuvey

asked only about their labour force status once every three months.

This pattern of probabilities should be viewed together with the gross flows which show that the number of unemployed persons (who were matched from one quarter to the next (ie UN+UE+UU) increased by almost 100 percent from the earlier to the latter period, reflecting the growth in total unemployment numbers between the two periods.

The transition probabilities for persons not in the labour force remained largely unchanged over the period of observation. This may be partially because the not in the labour force group includes people who are retired, an inherently stable group of people who are unlikely to change their labour force status. Therefore, while an increase in a flow from unemployment may register a substantial change in the transitional probability, the same size increase in a flow from the not in the labour force group may not noticeably alter the transitional probability.

The transitional probabilities show that persons not in the labour force are very likely to remain that way ( 89 percent probability), while the chance of moving to unemployment and employment were 4 percent and 7 percent respectively (for the later period). Although the transitional probability NE is quite small, it actually involves a much larger number of people than the transitional probability UE. Therefore, while an unemployed person is
Figure 2. Transition Probabilities

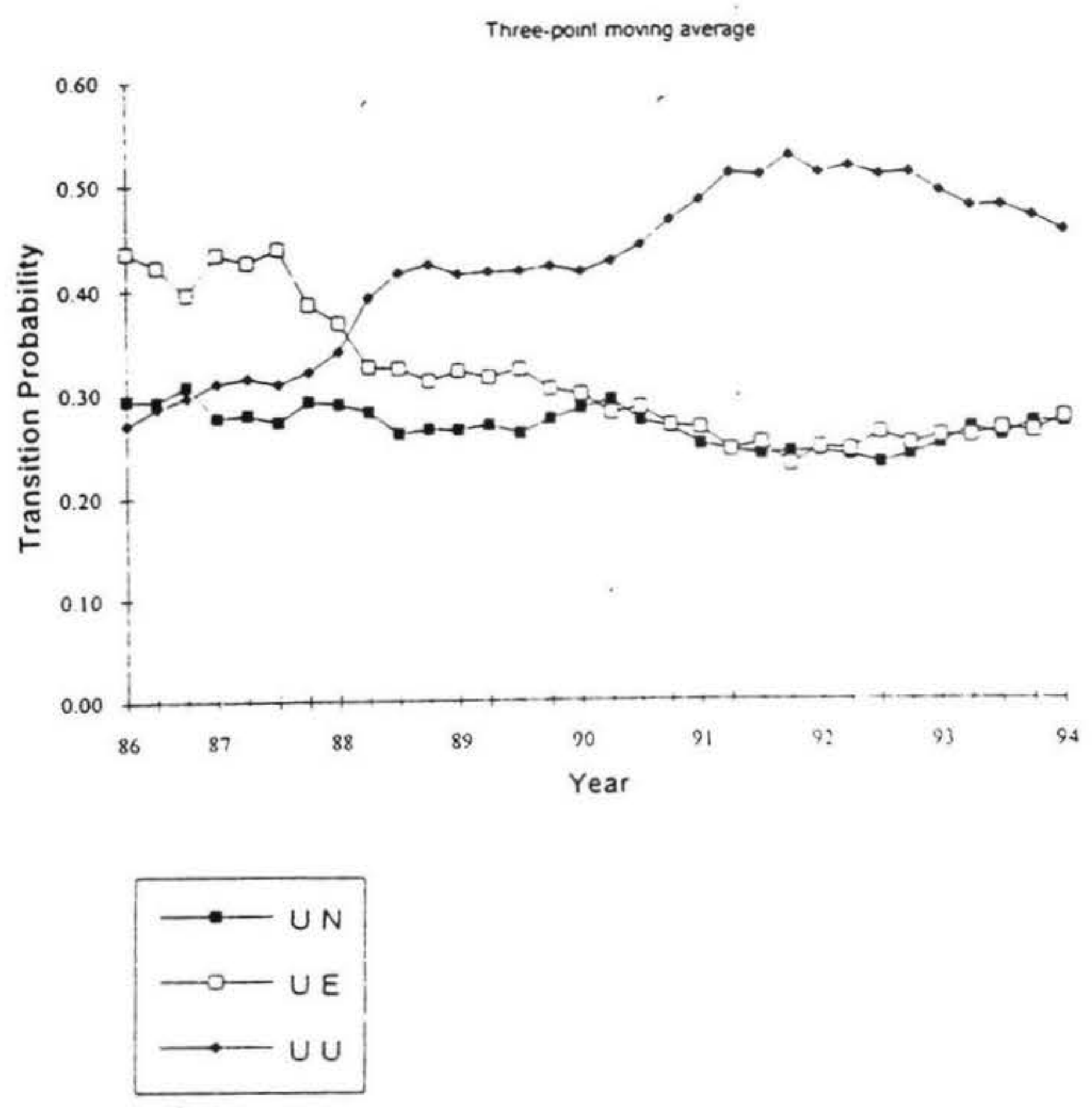

\begin{tabular}{llll} 
& UN & UE & UU \\
86 & 0.29 & 0.44 & 0.27 \\
& 0.29 & 0.42 & 0.29 \\
& 0.31 & 0.40 & 0.30 \\
87 & 0.28 & 0.43 & 0.31 \\
& 0.28 & 0.43 & 0.32 \\
& 0.27 & 0.44 & 0.31 \\
& 0.29 & 0.39 & 0.32 \\
88 & 0.29 & 0.37 & 0.34 \\
& 0.28 & 0.33 & 0.39 \\
& 0.26 & 0.32 & 0.42 \\
& 0.26 & 0.31 & 0.42 \\
89 & 0.29 & 0.37 & 0.34 \\
& 0.28 & 0.33 & 0.39 \\
& 0.26 & 0.32 & 0.42 \\
90 & 0.28 & 0.30 & 0.42 \\
& 0.29 & 0.28 & 0.43 \\
& 0.27 & 0.29 & 0.44 \\
& 0.27 & 0.30 & 0.42 \\
91 & 0.25 & 0.27 & 0.48 \\
& 0.24 & 0.24 & 0.51 \\
& 0.24 & 0.25 & 0.51 \\
& 0.24 & 0.23 & 0.53 \\
92 & 0.24 & 0.25 & 0.51 \\
& 0.24 & 0.24 & 0.52 \\
& 0.23 & 0.26 & 0.51 \\
93 & 0.24 & 0.25 & 0.51 \\
93 & 0.25 & 0.26 & 0.49 \\
& 0.26 & 0.26 & 0.48 \\
& 0.26 & 0.26 & 0.48 \\
& 0.27 & 0.26 & 0.47 \\
& 0.27 & 0.28 & 0.46 \\
\hline \multirow{4}{*}{9}
\end{tabular}


much more likely to be employed in the following quarter than a person who is not in the labour force, the number of people moving from out of the labour force into employment is much larger than the number moving from unemployment to employment.

\section{Annual transition probabilities}

The changes in the transition probabilities from unemployment over the past eight years are shown in Figure 2. In 1986, unemployed people were far more likely to be employed in the following quarter than remaining as unemployed or moving to not in the labour force status. However, during the late 1980 s it became increasing more likely that an unemployed person would remain unemployed from one quarter to the next than obtain employment. Furthermore, from the early 1990 s, it became no more likely that an unemployed person would obtain employment than withdraw from the labour force. These changes reflect a labour force participation rate which was generally falling from 1987. From 1992, the probability of unemployed people being employed and being not in the labour force in the next quarter began to increase, while the probability of being unemployed began to fall. Recent falls in the unemployment rate confirm this pattern.

\section{Part-time / fulltime status}

Table 4 shows gross flows and transitional probabilities for the unemployed by part-time / fulltime status. In the earlier period, it appears that persons seeking fulltime work were more likely to obtain employment than those seeking part-time employment. The transition probability UE for fulltime was 0.36 compared to part-time of 0.33 . In the latter period, the number of (matched) unemployed increased by almost 100 percent, while the proportion of unemployed who were part-time job seekers decreased from 25.3 percent to 20.6 percent. In this period, whether a person was seeking fulltime or part-time employment seemed to have little effect on the probability of being employed in the next quarter.
The transitional probabilities, UN, indicate that those unemployed persons who are seeking part-time work are much more likely to withdraw from the labour force than those seeking fulltime work. In the March 1986 to March 1990 period, the probability, UN, for fulltime was 0.22 , while for part-time it was 0.44 . The transitional probabilities for the latter period show the same relationship, although while part-time job seekers were slightly more likely to withdraw from the labour force than before, fulltime job seekers were slightly less likely.

The transition probability UU shows that in more recent years fulltime job seekers have a 54 percent chance of remaining unemployed from one quarter to the next, while for part-time job seekers the chance is lower at 29 percent. This indicates that people seeking fulltime work continue to seek work for longer periods than those seeking parttime work. In the earlier period, both fulltime and parttime seekers were much less likely to be unemployed in consecutive quarters. Part-time workers, again, had a much lower UU. Although, in this period most of the difference between UU for part-time and fulltime can be also explained by the fact that fulltime job seekers were more persistent, a small part of the difference resulted from fulltime workers being more likely to obtain employment than part-time workers.

Influencing the differences in UU and UN for part-time and fulltime job seekers may be the mix of males and females within each status. Over the past eight years, there has been a large difference in the proportion of unemployed females looking for part-time work and the corresponding proportion of males. In the year to March 1994, this proportion was 32.8 percent for females, while for males the figure was only 8.8 percent. Apart from a narrowing in $1988 / 89$, these proportions have fluctuated only slightly since $1987 / 88$ when 41.0 percent of unemployed females were looking for part-time work, compared with 9.9 percent of males. Therefore, females are much more likely than males to be among those job seekers who have a relatively high probability of leaving the labour

Table 4: Gross flows and transition probabilities, by part-time / full-time status 1986 to 1994

\begin{tabular}{|c|c|c|c|c|c|c|}
\hline & \multirow[b]{2}{*}{ Full-time } & \multicolumn{2}{|c|}{1986 to 1990} & \multicolumn{2}{|c|}{1990 to 1994} & \multirow[b]{2}{*}{ Total } \\
\hline & & Part-time & Total & Full-time & Part-time & \\
\hline \multicolumn{7}{|c|}{ Gross flows $(000 \mathrm{~s})$} \\
\hline UN & 8.9 & 6.1 & 15.0 & 16.6 & 10.3 & 26.9 \\
\hline UE & 14.7 & 4.5 & 19.4 & 21.9 & 5.5 & 27.4 \\
\hline UU & 16.9 & 3.1 & 20.0 & 47.2 & 6.4 & 53.6 \\
\hline \multicolumn{7}{|c|}{ Transitional probabilities } \\
\hline UN & 0.22 & 0.44 & 0.28 & 0.20 & 0.46 & 0.25 \\
\hline UE & 0.36 & 0.33 & 0.36 & 0.26 & 0.25 & 0.26 \\
\hline UU & 0.42 & 0.23 & 0.37 & 0.54 & 0.29 & 0.49 \\
\hline
\end{tabular}

Source: Household Labour Force Survey 


\begin{tabular}{lllllll}
\hline & $\begin{array}{l}\text { Never } \\
\text { worked }\end{array}$ & $\begin{array}{l}\text { Up to 6 } \\
\text { months }\end{array}$ & $\begin{array}{l}6 \text { to } 12 \\
\text { months }\end{array}$ & $\begin{array}{l}1 \text { to 2 } \\
\text { years }\end{array}$ & $\begin{array}{l}\text { Over } \\
\text { 2 years }\end{array}$ & Total \\
\hline & & & \multicolumn{2}{l}{ Gross-flows $(000$ s) } & & \\
NN & 75.7 & 49.4 & 15.3 & 41.2 & 439.7 & 638.0 \\
NE & 10.2 & 16.0 & 3.3 & 4.8 & 12.6 & 47.9 \\
NU & 6.1 & 7.3 & 2.3 & 4.0 & 9.8 & 30.3 \\
UN & 3.8 & 7.3 & 2.1 & 4.3 & 8.7 & 26.9 \\
UE & 2.3 & 15.0 & 3.0 & 3.4 & 3.2 & 27.4 \\
UU & 5.5 & 17.5 & 5.5 & 9.7 & 14.2 & 53.6 \\
& & & & & & \\
NN & 0.82 & 0.67 & 0.72 & 0.82 & 0.95 & 0.89 \\
NE & 0.11 & 0.23 & 0.16 & 0.10 & 0.03 & 0.07 \\
NU & 0.07 & 0.10 & 0.11 & 0.08 & 0.02 & 0.04 \\
UN & 0.33 & 0.19 & 0.20 & 0.25 & 0.34 & 0.25 \\
UE & 0.21 & 0.38 & 0.28 & 0.20 & 0.13 & 0.26 \\
UU & 0.46 & 0.43 & 0.52 & 0.55 & 0.54 & 0.49 \\
\hline
\end{tabular}

Source: Household Labour Force Survey

force, while males are much more likely than females to be among those are unemployed in consecutive quarters. Similarly, a relatively larger number of unemployed 15-19 year-olds are part-time job seekers. These younger people are therefore more likely than those in the older age groups to be among those who have a relatively high probability of leaving the labour force.

\section{Work experience}

The term 'work experience' will refer to the length of time since a job was held. Gross-flows of work experience is only available for the latter period of September 1990 to June 1994. Table 5 shows that the probability of moving from unemployment into employment varies substantially with work experience. The probability UE falls with the length of time since a job was last held. While for people who were last employed inside of six months, the average transition probability UE is 0.38 , for people who have not worked for over two years the probability is 0.13 . For people who have never worked, the probability of moving from employment to unemployment at 0.22 is lower than for all people who have inside of one year. The relatively high levels of unemployment among the younger age groups are partially a reflection of this probability.

The gross-flows figures show that more than half of the unemployed people who moved into employment last year had a job in the previous six months.

Similar patterns are apparent among the transition probabilities from unemployment to not in the labour force and from unemployment to unemployment. Unemployed people who have not worked for some time are more likely to withdraw from the labour force than those who have more recent work experience. However, the spread of the UN probabilities is not as marked as those of UE. This suggests that the length of time since a person last worked is more strongly associated with the probability of obtaining employment than with their probability of withdrawing from the labour force. Moreover, although the likelihood of remaining unemployed from one quarter to the next increases with the time since the respondent last worked, the influence of work experience on this transition is even less pror.ounced than on the transition from unemployment to employment or out of the labour force.

Table 5 shows that of all people not in the labour force, the people most likely to enter the labour force are those who have worked most recently (in other words, the longer a person not in the labour force has been without a job, the less likely they are to re-enter the labour force). By comparison, the gross flows show that the number of people entering the labour force is far more numerous among those who have not worked for over two years, than among all other categories combined. However, although the flow of people who have not worked for over two years from not in the labour force is relatively large, the 'stock' of persons who have not worked for over two years is much larger. The transition probability for this group is therefore low.

The range of the transition probabilities for UE is greater than the range for NE. This suggests that, on average, work experience has more influence on the transition of unemployed persons into employment than on the transition from not in the labour force to employment.

\section{Occupation sought}

An analysis of the various transition probabilities by occupation sought shows that unemployed persons seek- 


\begin{tabular}{|c|c|c|c|c|c|}
\hline & $\begin{array}{l}\text { Clerical and } \\
\text { related work }\end{array}$ & $\begin{array}{l}\text { Service } \\
\text { and sales }\end{array}$ & $\begin{array}{l}\text { Production and } \\
\text { transport wokers } \\
\text { and labourers }\end{array}$ & Other & Total \\
\hline & & & \multicolumn{3}{|l|}{ Gross flows $(000 \mathrm{~s})$} \\
\hline UN & 1.9 & 2.9 & 3.3 & 1.6 & 15.0 \\
\hline UE & 2.4 & 2.5 & 3.6 & 2.2 & 19.4 \\
\hline \multirow[t]{2}{*}{ UU } & 2.1 & 2.7 & 6.9 & 2.4 & 20.0 \\
\hline & & & \multicolumn{3}{|c|}{ Transition probabilities } \\
\hline UN & 0.30 & 0.36 & 0.24 & 0.26 & 0.28 \\
\hline UE & 0.37 & 0.30 & 0.26 & 0.36 & 0.36 \\
\hline UU & 0.33 & 0.34 & 0.50 & 0.39 & 0.37 \\
\hline
\end{tabular}

Source: Household Labour Force Survey

Table 6b: Groos flows and transition probabilities by occupation sought, 1991 - 1994

\begin{tabular}{lllllll}
\hline & $\begin{array}{l}\text { Managers } \\
\text { professionals } \\
\text { and technicians Clerks }\end{array}$ & $\begin{array}{l}\text { Service } \\
\text { and sales }\end{array}$ & $\begin{array}{l}\text { Elementary } \\
\text { occupations }\end{array}$ & Other & Total \\
\hline & & & \multicolumn{2}{l}{ Gross flows (000s) } \\
UN & 2.4 & 2.9 & 4.7 & 4.1 & 4.6 & 25.6 \\
UE & 3.8 & 3.2 & 3.2 & 2.7 & 5.1 & 25.9 \\
UU & 5.9 & 6.1 & 6.2 & 9.9 & 13.2 & 52.5 \\
& & & & Transition probabilities & & \\
UN & 0.21 & 0.23 & 0.33 & 0.27 & 0.20 & 0.25 \\
UE & 0.32 & 0.26 & 0.24 & 0.17 & 0.23 & 0.26 \\
UU & 0.47 & 0.50 & 0.43 & 0.56 & 0.57 & 0.49 \\
\hline
\end{tabular}

Source: Household Labour Force Survey

ing work in the higher skilled jobs are more likely to find work. For example, the probability of an unemployed person obtaining employment in as a manager, professional or technician was 0.32 for the period June 1991 to June 1994. The comparable probability for a person seeking work in an elementary occupation is 0.17 . Data limitations prevent a full comparison with the period March 1986 to March 1990.6 Nevertheless, the data that are available display a similar pattern.

It does not follow that higher skilled jobs are easier to find than lower skilled jobs. It is more likely that higher skilled job seekers are the ones who seek higher skilled jobs, and these higher skilled job seekers are more successful at finding employment. In other words 'job seeker skill' is probably a stronger determinant of UE than the type of job being sought. In fact 'job seeker skill' is probably more explanatory of the patterns in Table $6 \mathrm{a}$ and $6 \mathrm{~b}$ than occupation sought.

The transition probabilities UU and UN do not show the same correlation with skill level or occupation as UE does. Unemployed persons who are seeking service or sales positions are most likely to exit the labour force, while persons seeking work in elementary and 'other' occupations are the most likely to remain unemployed from one quarter to the next.

\section{Educational attainment}

Not surprisingly, unemployed people with both postschool qualifications and school qualifications are most likely to obtain employment. Unemployed people with school qualifications only are slightly more likely to obtain employment than those with post-school qualifications only, while those with no qualifications are the least likely to obtain employment. While the likelihood of moving from unemployment to employment fell for all educational groups from the earlier period to the later, the size of the various probabilities, relative to each other changed. For example, in the period March 1986 to March 1990 , an unemployed person with both school and postschool qualifications had a 49 percent chance of being employed in the subsequent period. This is just over one and a half times (1.58) the chance of persons with no qualifications. In the September 1990 to June 1994 period, 


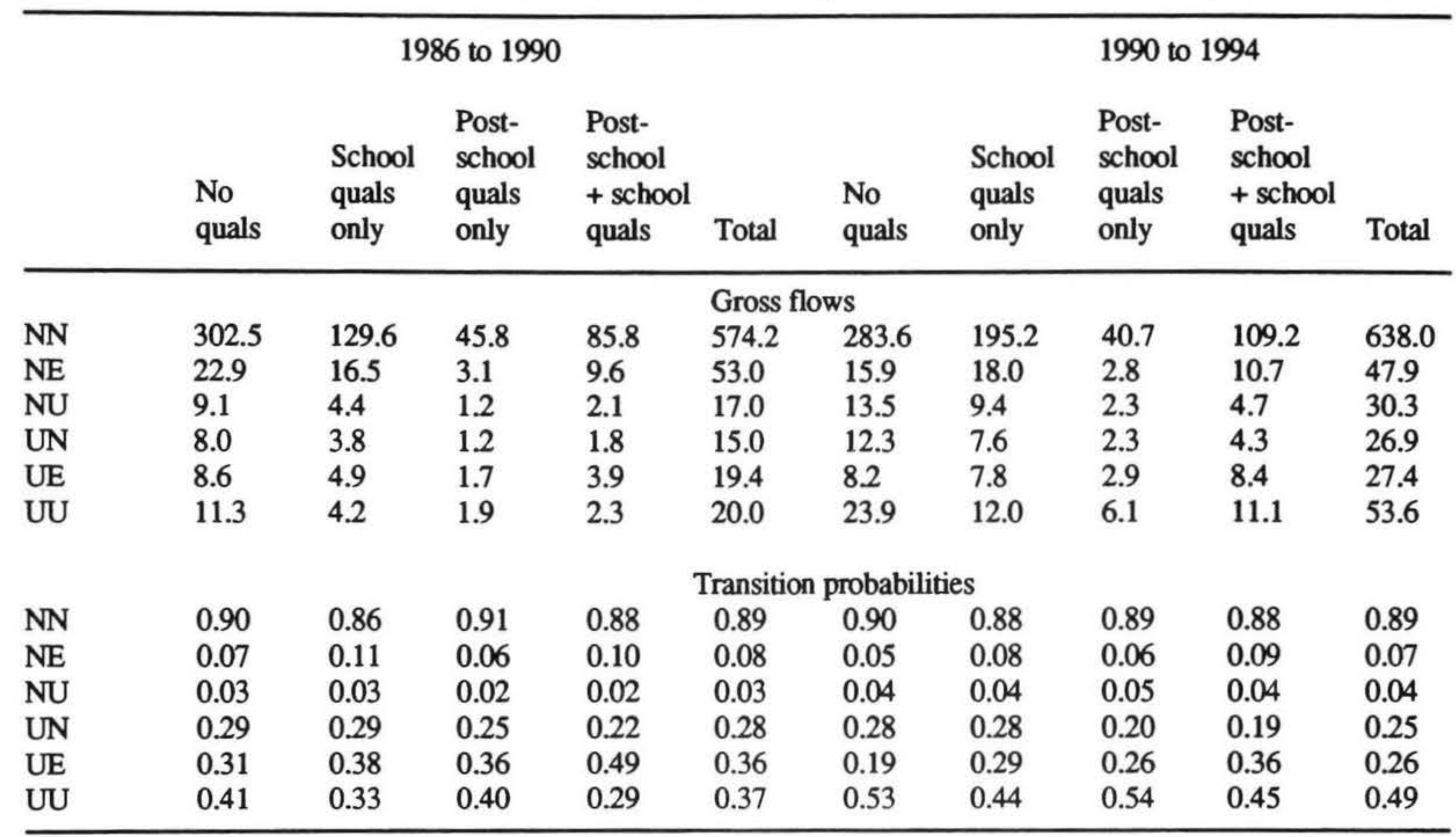

Source: Household Labour Force Survey

a person with both post-school and school qualifications was almost twice as likely (1.89) to obtain employment in the following quarter.

Although unemployed people with post-school qualifications only are less likely to obtain employment than those with both school and post school qualifications, they have about the same probability of withdrawing from the labour force. This is reflected in the fact that persons with postschool qualifications only are more likely than most to remain unemployed from one quarter to the next. This suggests that although unemployed people with postschool qualifications only are slightly less likely than those with school qualifications only to obtain employment, they are more willing to continue job search activities in the face of continued unemployment.

Unemployed people without post-school qualifications are more likely to leave the labour force than those with post-school qualifications. However, for those with no qualifications, this does not appear to be because they are unwilling to face repeated spells of unemployment. The probability UU is highest for this group.

Educational attainment does not seem to be an important influence on whether people who are not in the labour force remain not in the labour force. There is very little difference in transition probabilities of NN, NE and NU among the four levels of educational attainment.

\section{Job search method}

People who are unemployed use a variety job search methods. Table 8 shows that the most successful job search method appears to be contacting careers advisors or private employment agencies. In the period September 1990 to June 1994 unemployed persons using this method had a 32 percent chance of being employed in the following quarter. However, fewer people used this form of job search than any other method. In contrast, one of the least effective job search methods, looking at job advertisements in the newspaper, was the most commonly used method. Persons using this method to find work had a 23 percent chance of obtaining employment in the period September 1990 to June 1994.

The figures therefore suggest that the most effective job search method is used by the fewest number of unemployed people. Moreover, this apparent contradiction is understated by the figures. The various job search methods are not mutually exclusive, therefore a person may be represented in more than one category. Hence, many of the people who contacted a private employment agency or careers advisor may also have looked in the newspaper and therefore created an upward effect on the transition probability UE for the newspaper search category. However, people who are successful in obtaining employment may be successful because they utilise several different methods of job search (including both the common and the successful methods and the less common and less successful methods), rather than because they utilise any one particular job search method. If this is true, then the relatively few people who contact a careers advisor or a private employment agency may be successful because this is one of several job search activities they employ.

It is interesting to note that while figures for "other/not specified' are only available for the later period, this method of job search appears to be the most effective. This 


\begin{tabular}{|c|c|c|c|c|c|c|c|c|c|c|c|c|c|}
\hline & $\begin{array}{l}\text { News } \\
\text { paper } \\
\text { search }\end{array}$ & $\begin{array}{l}\text { Applied } \\
\text { in } \\
\text { person }\end{array}$ & $\begin{array}{l}\text { Contact } \\
\text { the } \\
\text { DoL }\end{array}$ & $\begin{array}{l}\text { Contact } \\
\text { fiends/ } \\
\text { relatives }\end{array}$ & $\begin{array}{l}\text { Contacted } \\
\text { careers } \\
\text { advisors/ } \\
\text { pivate } \\
\text { agencies }\end{array}$ & Total & $\begin{array}{l}\text { News } \\
\text { paper } \\
\text { search }\end{array}$ & $\begin{array}{l}\text { Applied } \\
\text { in } \\
\text { person }\end{array}$ & $\begin{array}{l}\text { Contact } \\
\text { the } \\
\text { DoL }\end{array}$ & $\begin{array}{l}\text { Contact } \\
\text { fiends/ } \\
\text { relatives }\end{array}$ & $\begin{array}{l}\text { Contacted } \\
\text { careers } \\
\text { advisors/ } \\
\text { pivate } \\
\text { agencies }\end{array}$ & $\begin{array}{l}\text { Otherd } \\
\text { not } \\
\text { spec- } \\
\text { ified }\end{array}$ & Toal \\
\hline & \multicolumn{13}{|c|}{ Gross flows (000s) } \\
\hline UN & 11.2 & 7.9 & 5.9 & 6.4 & 1.9 & 15.0 & 21.7 & 13.2 & 14.1 & 13.5 & 3.3 & 4.5 & 26.9 \\
\hline UE & 127 & 10.1 & 7.7 & 7.5 & 3.4 & 19.4 & 20.6 & 15.3 & 152 & 13.1 & 5.1 & 8.4 & 27.4 \\
\hline UU & 17.3 & 11.9 & 13.7 & 10.0 & 3.2 & 20.0 & 48.3 & 29.9 & 420 & 29.4 & 8.0 & 7.9 & 53.6 \\
\hline \multicolumn{14}{|c|}{ Transition probabilities } \\
\hline UN & 0.27 & 0.27 & 0.22 & 0.27 & 0.22 & 0.28 & 0.24 & 0.23 & 0.20 & 0.24 & 0.21 & 0.22 & 0.25 \\
\hline UE & 0.31 & 0.34 & 0.28 & 0.31 & 0.40 & 0.36 & 0.23 & 0.27 & 0.22 & 0.24 & 0.32 & 0.40 & 0.26 \\
\hline UU & 0.42 & 0.40 & 0.50 & 0.42 & 0.37 & 0.37 & 0.53 & 0.50 & 0.58 & 0.51 & 0.48 & 0.37 & 0.49 \\
\hline
\end{tabular}

Source: Household Labour Force Survey

suggests that unemployed people are using methods of job search which are not captured in the HLFS, but which are more effective than any of those listed as response categories in the HLFS. However, as stated above, the apparent effectiveness of these 'other' methods may be simply because persons using these methods are active in a whole range of job search activities.

Contacting the Department of Labour is the job search method associated with the highest probability of being unemployed from one quarter to the next and also with the lowest chance of persons withdrawing from the labour force. There are probably many people whose only job search method is 'contacting the Department of Labour'. This does not necessarily mean that these people actually look at jobs on the vacancy boards of the New Zealand Employment Service, rather, it could be that these people merely registered their name with the Service (so they could be entitled to a benefit). For this reason, this method of job search may in fact be much less intense than any of the others. This would explain the high UU probability, but also the low UN probability as persons with less intensive search methods are less likely to give up 'searching' because the search itself requires less effort than some other methods.

It is interesting to note the difference in UE for 'contacting the Department of Labour' $(0.22)$ and 'contacted a careers advisor or private employment agency' $(0.32)$. Both methods involve job placement agencies. However, the private employment agencies typically have clients with relatively high skill levels. Therefore, on the basis of the occupational transitional probabilities, it follows that this category records a higher UE than "contacting the Department of Labour'.

There does not seem to be any significant change in the relative effectiveness of the various job search methods from the earlier period to the later period. Each UE transition fell by a similar amount.

\section{Conclusion}

Each person's experience in the labour market is different. Some remain unemployed for a long period of time, while others find work relatively quickly. Moreover, many unemployed people leave the labour force without finding work. The findings of this paper suggest that relatively strong relationships exist between a person's personal characteristics or choices and their probability of moving between particular labour forces statuses.

The data contained in this paper update the information available on gross flows by incorporating data up to and including the June 1994 quarter. In addition to this, a comparison over time is presented, and disaggregations by part-time/fulltime status, occupation sought, work experience and job search method are presented for the first time.

The most notable findings of this paper are that:

* The probability of an unemployed person moving into employment has fallen significantly in the past eight years and is now similar to the probability of an unemployed person withdrawing from the labour force.

* Part-time job seekers have a similar chance of finding work to fulltime job seekers. However, the latter are much less likely to withdraw from the labour force and much more likely to remain unemployed from one quarter to the next.

*The probability of moving from unemployment to employment varies considerably with the length of time since a job was held.

* Unemployed people seeking high skill jobs are more likely to obtain employment than those seeking lower skill jobs. This is probably a reflection on the skill of the job seeker rather than the kind of job sought. 
* Unemployed people with both school and post-school qualifications are the most likely to obtain employment, followed by those with school qualifications only, postschool qualifications only, while those with no qualifications are the least likely to obtain employment

* The most effective job search method appears to be 'contacting a careers advisor or private employment agency'. However, this may be because people employing this method are those who employ the greatest number of methods.

\section{Future research}

The following questions about gross flows remain unanswered:

* Have the characteristics of the matched sample compared with the unmatched sample changed in recent years?

* How much does the problem of classification error impact on the analysis of gross flows?

* What kind of weighting system is appropriate for the analysis of flows over more than two quarters?

* What contribution would longitudinal analysis (over periods of more than two quarters) make to the study of gross-flows analysis?

* Does the analysis of flows between part-time and fulltime status provide any useful insights?

* To what extent do people move between different occupation and industry groups?

\section{References}

Grimmond, D. 1993a, Labour Force Dynamics in New Zealand NZIER Research Monograph 60, Wellington.

Grimmond, D. 1993, Unemployment duration: evidence from the Household Labour Force Survey. In Morrison, P.S. (ed) Labour, employment and work in New Zealand. Proceedings of the Fifth Conference, Victoria University of Wellington, Wellington : 29-37.

Woolf, J. 1989, Gross Flows Estimates from the Household Labour Force Survey, The New Zealand Labour Force September 1989 quarter.

\section{Notes}

1. The author acknowledges the assistance and advice given by Chris Pike, Robert Templeton and Julie Woolf.

2. Unfortunately, the Household Labour Force Survey (which provides the official measure of unemployment) is not able to provide a complete measure of long-term unemployment. This is because some survey respondents - those who are waiting to take up a new job within the next four weeks - are not asked how long he or she has been looking for work. Failure to collect duration data from all the unemployed means that the numbers and percentages of unemployed people who were long-term unemployed in any given year may differ slightly from the figures given in this paper.

3. Grimmond (1993a and b) provides a very thorough analysis gross-flows data using the variables listed as well as duration of unemployment.

4. Gross-flows estimates for the June 1990 quarter are unavailable. This is because the increase in the size of the survey between the March 1990 and June 1990 quarters was not conductive to the method of weight respondents in gross-flows calculations.

5. In calculating transition probabilities, flows data from the quarters December 1993 through to June 1994 have lower weights than data for other quarters. This is because the matched sample, reduced by one-quarter of the sample rotating, is significantly smaller during this period than the matched sample for quarters which involve the rotation of one-eighth of the sample.

6. Due to a revision of the classification of occupations, data from Tables $6 \mathrm{a}$ and $6 \mathrm{~b}$ are not comparable. However, as indicated by the categories in the table, some categories from the old classification relate, broadly, to some categories from the classification. A separate problem is the small size of some of the estimates. For this reason some occupational groups have been combined.

\section{Author}

Stuart Irvine is a Labour Market Analyst in the Labour Market Division of Statistics New Zealand, PO Box 2922, Wellington. 